\title{
Low-Impact Development:an Innovative Alternative Approach to Stormwater Management
}

\section{Chao-Hsien Liaw}

Associate Professor, Department of Harbor and River Engineering, National Taiwan Ocean University, Keelung, Taiwan 202, R.O.C.

Mow-Soung Cheng

Chief of Technical Support Section, Department of Environmental Resources, Prince George's County, Maryland, USA.

Yao-Lung Tsai

Graduate Student, Department of Harbor and River Engineering, National Taiwan Ocean University, Keelung, Taiwan 202, R.O.C.

Follow this and additional works at: https://jmstt.ntou.edu.tw/journal

Part of the Civil and Environmental Engineering Commons

\section{Recommended Citation}

Liaw, Chao-Hsien; Cheng, Mow-Soung; and Tsai, Yao-Lung (2000) "Low-Impact Development:an Innovative Alternative Approach to Stormwater Management," Journal of Marine Science and Technology. Vol. 8: Iss. 1, Article 5. DOI: $10.51400 / 2709-6998.2452$

Available at: https://jmstt.ntou.edu.tw/journal/vol8/iss1/5

This Research Article is brought to you for free and open access by Journal of Marine Science and Technology. It has been accepted for inclusion in Journal of Marine Science and Technology by an authorized editor of Journal of Marine Science and Technology. 


\title{
LOW-IMPACT DEVELOPMENT: AN INNOVATIVE ALTERNATIVE APPROACH TO STORMWATER MANAGEMENT
}

\author{
Chao-Hsien Liaw*, Mow-Soung Cheng** and Yao-Lung Tsai***
}

Keywords: Flood mitigation, Low-Impact Development, Stormwater management.

\section{ABSTRACT}

To assist local governments in their efforts to develop more effective stormwater management programs, an innovative comprehensive approach to stormwater management referred to as Low-Impact Development (LID) has been developed. Low-Impact Development technology employs microscale and distributed management techniques. This paper briefly outlines the development of LID technology and discusses its basic hydrological control principles. However, LID's source control techniques are an economical common sense approach that can be used to better manage new development or retrofit existing development. We believe that this new approach is a significant step forward towards advancing the state-of-the-art of stormwater management and will be a valuable and useful tool for local governments in their efforts to control urban runoff.

\section{INTRODUCTION}

With urban development relentlessly expanding, the need for effective stormwater management technology has never been greater. Responding to regulations or recognizing the need to address the adverse environmental impacts of urban runoff $[1,2]$, local governments are confronted with developing complex multi-objective stormwater management programs [3, 4]. Today's comprehensive program not only has to deal with runoff quantity and quality control but, may also have to address such complicated issues as: ecosystem restoration, combined sewer overflow reduction, fisheries protection, potable surface/ground water resources protection, and wetland, riparian buffer and

Paper Received June 6, 2000. Author for Correspondence: C. H. Liaw. *Associate Professor, Department of Harbor and River Engineering, National Taiwan Ocean University, Keelung, Taiwan 202, R.O.C.

**Chief of Technical Support Section, Department of Environmental Resources, Prince George's County, Maryland, USA.

***Graduate Student, Department of Harbor and River Engineering, National Taiwan Ocean University, Keelung, Taiwan 202, R.O.C. stream protection. Many practitioners and scholars are beginning to question the efficacy of current stormwater management technology to meet these new water/natural resources protection objectives $[5,6,7]$.

Typically, adverse stormwater impacts are mitigated by conservation of natural resources (forests, streams, floodplains and wetlands), zoning restrictions, increasing open space, structural controls, and nonstructural controls (pollution prevention, recycling and hazardous waste collection) to treat and manage runoff quantity and quality and reduce nonpoint sources. Many conventional stormwater mitigation approaches such as management ponds exhibit a number of inherent practical, environmental and economic limitations [8]. These include the inability to replicate predevelopment watershed hydrology, elevated water temperatures and costly maintenance burdens. For example, when stormwater ponds provide only detention, they do not change the total volume and frequency of discharge which may accelerate stream channel erosion changing stream morphology and adversely affecting aquatic habitat structure such as pools, riffles and shading needed to protect the biological integrity of aquatic biota. Furthermore, we design and construct every site with one basic overriding goal - to achieve good drainage. As a site is developed its hydrologic functions are first altered on a micro scale. The cumulative impacts of micro changes result in drastically altered hydrologic regime which we typically try to mitigate using end-ofpipe management practices. If we can design sites to achieve good drainage, why not design sites with the opposite objective to maintain predevelopment hydrologic functions?

With growing concerns about the economics and efficacy of conventional technology, exploring alternative stormwater management practices and strategies is needed. The success that was achieved with the pioneering development and use of bioretention (filtering/infiltrating runoff within small depressed landscaped areas) [9] lead them to believe that perhaps changing the form and function of the developed 
landscape could be an important tool in controlling urban runoff. In fact, they began to realize that through intelligent site design, you could not only reduce impacts, you could also begin to restore hydrologic functions. What was not known was how much of a watershed's hydrologic functions could be restored within a developed landscape.

It was soon realized that maximizing the efficiency of conventional conservation measures and stormwater management practices could not reasonably be used to maintain or restore watershed functions. A new philosophical approach was needed. The approach chosen was really an old one. LID's basic principles were modeled after and borrowed from nature - managing rainfall at the source using uniform distribution of micro-scale controls. If you think of a forest, stormwater is controlled by a variety of mechanisms (interception by vegetation, small depression storage, channel storage, infiltration and evaporation, etc.) that are uniformly distributed throughout the landscape.

LID tries to mimic these mechanisms by uniformly distributing small infiltration, storage, retention, and detention measures throughout the developed landscape. With LID, every development feature (green space, landscaping, grading, streetscapes, roads, parking lots) is designed to reduce impacts or provide/maintain beneficial hydrologic functions.

\section{LID GENERAL}

LID controls stormwater at the source by creating a hydrological functional landscape that mimics natural watershed hydrology. This is achieved by creatively integrating hydrologic functions (volume, frequency, recharge and discharge) into site designs using four basic planning and design management principles. First, minimize impacts to the extent practicable by reducing imperviousness, conserving natural resources/ ecosystems, maintaining natural drainage courses, reducing use of curbs, gutters and pipes, and minimizing clearing and grading. Second, provide runoff storage measures dispersed uniformly throughout the landscape with the use of a variety of small-decentralized detention, retention, and runoff practices. Third, maintain predevelopment time of concentration by strategically routing flows to maintain travel time and control discharge. Fourth, implement effective public education programs to encourage property owners to use pollution prevention measures and maintain on lot management practices.

\section{LID BASIC SITE PLANNING STRATEGIES}

The first step of LID is to minimize or prevent runoff. This step is similar to traditional techniques of maximizing natural resource conservation, limiting disturbance, and reducing impervious areas. The major difference is with LID you must carefully consider how best to make use of the hydrologic soil groups and site topography to reduce and control runoff. These considerations include: 1) maintaining natural drainage patterns, topography and depressions, 2) preserving as much existing vegetation as possible in pervious soils, hydrologic soil groups A and B, 3) locating Best Management Practices (BMP) in pervious soils hydrologic soil groups $\mathrm{A}$ and $\mathrm{B}, 4$ ) directing impervious areas to less pervious soil groups $\mathrm{C}$ and $\mathrm{D}, 5$ ) disconnecting impervious surfaces to direct and disburse runoff to soil groups $\mathrm{A}$ and $\mathrm{B}, 6$ ) flattening slopes within cleared areas to facilitate on-lot storage and infiltration , 7) re-vegetating cleared and graded areas, and 8) maintaining travel time to increase infiltration and evaporation.

\section{LID HYDROLOGIC ANALYSIS AND RESPONSE}

\section{Suitability of Existing Stormwater Models for Microscale Simulations}

To implement LID concepts on a broad scale, analysis tools should include some level of process simulation to take into account site-specific factors that influence performance. Three types of commonly used runoff estimation methods are briefly summarized and discussed below:

\section{Rational method}

The rational method is probably the most widely used peak runoff estimation method. Commonly expressed as $Q_{p}=C i A$, where $Q_{p}$ is the peak runoff rate in $\mathrm{cms}, \mathrm{A}$ is the area contributing runoff in $\mathrm{km}^{2}$, $\mathrm{i}$ is the rainfall intensity in $\mathrm{cm}$ per hour, and $\mathrm{C}$ is the runoff coefficient. The rational method is used to estimate the peak flow resulting from a given rainfall intensity over a small area. The problems and pitfalls associated with the rational methods are well known. The rational method does not address the temporal distribution of runoff or the total storm volume, two important considerations for LID systems. Due to the lack of any explicit information pertaining to soil storage, the rational method has little to offer LID modeling other than for rough calculations on the effect of LID on traditional peak flow calculations.

\section{Unit hydrograph}

The rational method described above is a special 
case of the Unit Hydrograph (UH) method [10]. The UH has long and successful history in rainfall/runoff estimation. The UH is a linear transform function that is applied to a time series of rainfall, resulting in an output hydrograph $[11,12]$. The ordinates of the UH are generally obtained from measured sets of rainfall and runoff. However, hydrologic process information is only implicitly included in the ordinates of the transform. They have no direct physical meaning. The UH method is inadequate for the simulation of controls that are designed to alter the hydrology. Therefore, UH method, like the rational method, appears to be ill suited for LID process modeling.

\section{Soil Conservation Service (SCS) method}

While the SCS method may be characterized as an extension of UH method [13,14], it shows more promise for LID controls because soil moisture storage is explicitly treated $[15,16,17]$. The SCS method is not recommended for predicting runoff from small storms. The SCS method is a popular design tool because it is sensitive to site-specific conditions, and a great deal of data (generally based on soils, slope and land use) is available. Various surface conditions may be simulated and paired with cost information for further consideration.

The SCS method is based on dividing precipitation $(P(\mathrm{~mm}))$ into three components, direct runoff $(Q)$, initial abstraction $\left(I_{a}(\mathrm{~mm})\right)$, and actual retention $(F)$ [14]. The following relationship is assumed among terms and is mathematical expression of the SCS hypothesis:

$$
\frac{F}{S}=\frac{Q}{P-I_{a}}
$$

In which $S$ is the potential maximum retention. The actual retention is

$$
F(m m)=\left(P-I_{a}\right)-Q
$$

Substituting Eq. (2) into Eq. (1) and rearranging to solve for $Q$ :

$$
Q(m m)=\frac{\left(P-I_{a}\right)^{2}}{P-I_{a}+S}
$$

Empirical evidence has shown that $I_{a}=0.2 S[13$, 14, 17]. Substituting this into Eq. (3) yields the basic equation for calculating the runoff depth, $Q$, for a rainfall depth, $P$.

$$
Q=\frac{(P-0.2 S)^{2}}{P+0.8 S}
$$

An empirical analysis was performed to relate the runoff $\mathrm{CN}$ (curve number) and $S$, for use in Eq. (4). Hence, an empirical analysis led to the following relationship:

$$
S(m m)=\frac{25400}{\mathrm{CN}}-254
$$

The Soil Conservation Service (SCS) also provides an equation for estimating the watershed lag, which is defined as the time in hours from the center of mass of the excess rainfall to the peak discharge. They also indicate that the time of concentration $\left(t_{c}\right)$ equals 1 . 67 times the lag. Thus, $t_{c}$ in hour is

$$
t_{c}=\frac{L^{0.8}\left(\frac{1000}{C N}-9\right)^{0.7}}{2946 \sqrt{I}}
$$

in which $L$ is the watershed length $(\mathrm{m})$ and $I$ is the watershed slope $(\mathrm{m} / \mathrm{m})$. Eq. (6) indicates that $t_{c}$ will increase as the $\mathrm{CN}$ is reduced. This change can lead to a large arriving time in flood peak.

Due to its widespread use and available soils database, the SCS method is well suited for initial screening of LID impacts.

\section{Hydrologic Analysis}

The objective of LID site design is to minimize, detain and retain the post development runoff volume uniformly throughout the site to mimic predevelopment hydrologic functions. Uniform dispersion of small on lot retention and detention to control both runoff discharge volume and rate is the key to better replication of predevelopment hydrology. The relative change in the frequency and duration of runoff are also much closer to predevelopment conditions than can be achieved by typical application of conventional BMPs. Management of both runoff volume and peak runoff rate is both included in the design of controls. This is in contrast to conventional end-of-pipe treatment that completely alters the watershed hydrology to create a new modified hydrologic regime.

The LID site analysis and design approach focus on four major elements. These fundamental factors affect site hydrology and are introduced below.

Curve Number $(\mathrm{CN})$ - A factor that accounts for the effects of soils and land cover on the amount runoff generated. Minimizing the magnitude of change from the predevelopment to the post development $\mathrm{CN}$ by reducing impervious areas and preserving more natural vegetation will reduce runoff storage requirements and help to maintain predevelopment runoff volume.

Time of concentration (Tc) - The time it takes runoff to travel through the watershed. Maintaining the 
Table 1. Low-Impact Development planning techniques to reduce the post development Low-Impact Development CN

\begin{tabular}{|c|c|c|c|c|c|c|}
\hline $\begin{array}{l}\text { Suggested options affecting } \\
\text { curve number }\end{array}$ & Land cover type & $\begin{array}{c}\text { Percent of } \\
\text { imperiousness }\end{array}$ & $\begin{array}{l}\text { Hydrologic soils } \\
\text { group }\end{array}$ & Hydrologic condition & $\begin{array}{l}\text { Disconnectivity of } \\
\text { impervious area }\end{array}$ & $\begin{array}{l}\text { Storage and } \\
\text { infiltration }\end{array}$ \\
\hline Limit use of sidewalks & & $\mathrm{X}$ & & & $\mathrm{X}$ & \\
\hline Reduce road length and width & & $\mathrm{X}$ & & & $\mathrm{X}$ & \\
\hline $\begin{array}{l}\text { Reduce driveway length } \\
\text { and width }\end{array}$ & & $\mathrm{X}$ & & & $\mathrm{X}$ & \\
\hline $\begin{array}{l}\text { Conserve natural } \\
\text { resources areas }\end{array}$ & $\mathrm{X}$ & & $\mathrm{X}$ & $\mathrm{X}$ & & \\
\hline Minimize disturbance & $\mathrm{X}$ & & & $\mathrm{X}$ & & \\
\hline $\begin{array}{l}\text { Preserve infiltratable soils } \\
\text { Preserve natural }\end{array}$ & & & $\mathrm{X}$ & $\mathrm{X}$ & & \\
\hline depression areas & & & & & & $X$ \\
\hline Use transition zones & $\mathrm{X}$ & $\mathrm{X}$ & & & & \\
\hline Use vegetated swales & $\mathrm{X}$ & & & & & \\
\hline Preserve vegetation & $\mathrm{X}$ & & & & & $\mathrm{X}$ \\
\hline
\end{tabular}

predevelopment $\mathrm{Tc}$ reduces peak runoff rates and can be achieved by lengthening flow paths, reducing the use of pipes and paved channels, and conservation of natural drainage and depression storage.

Permanent storage areas (Retention) - Retention storage is needed for volume and peak control, as well as water quality control and to maintain the same $\mathrm{CN}$ as the predevelopment condition.

Temporary storage areas (Detention) - Detention storage may be needed to maintain the peak runoff rate or to prevent flooding.

\section{Minimizing the change in $C N$}

Calculation of the LID CN is based on a detailed evaluation of the existing and proposed land cover so that an accurate representation of the potential for runoff can be obtained. This calculation requires the engineer/planner to investigate the following key parameters associated with LID: 1) land cover type, 2) percentage of and connectivity of impervious cover, 3 ) hydrologic soils group (HSG), 4) hydrologic conditions (average moisture or runoff conditions), and 5) maintaining existing drainage patterns and natural retention features.

The following are examples of LID site planing practices that can be utilized to achieve a substantial reduction in the change of the calculated $\mathrm{CN}$ : 1) narrower driveways and roads (minimizing impervious areas), 2) maximized tree preservation and/or forestation, 3) site finger printing (minimal disturbance), open drainage swales, 4) preservation of soils with high infiltration rates, 5) location of BMPs on high-infiltration soils, and 6) construction of impervious features on soils with low infiltration rates. Reducing the change in
$\mathrm{CN}$ alone will reduce both the post development peak discharge rate and volume. Eq. (5) shows how LID site planning can affect components of the $\mathrm{CN}$, resulting in lower $\mathrm{CN}$ and more infiltration.

Table 1 provides a list of Low-Impact Development site planning practices and their relationship to the components of the Low-Impact Development CN. Key low-impact techniques that will reduce the post development $\mathrm{CN}$, and corresponding runoff volumes, are as follows:

Fig. 1 illustrates the hydrologic response using LID techniques to reduce the impervious areas and increase the storage volume.

- Hydrograph 1 represents the response of a predevelopment condition.

- Hydrograph 2 represents the response of a post devel-

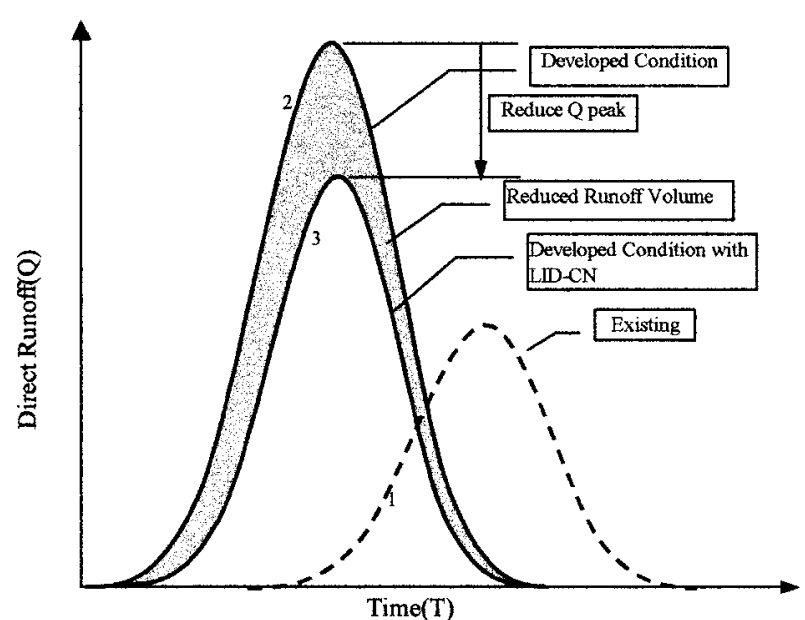

Fig. 1. Effect of Low-Impact Development CN on the post development hydrograph. 
Table 2. Low-Impact Development techniques to maintain the predevelopment time of concentration

\begin{tabular}{|c|c|c|c|c|c|c|}
\hline & Low-Impact & Minimize disturbance & Flatten grades & Reduce height of slopes & Increase flow path & Increase roughness " $n$ " \\
\hline & On-lot bioretention & $\mathrm{X}$ & & & & $\mathrm{X}$ \\
\hline$\ddot{q}$ & Wider and flatter swales & & $\mathrm{X}$ & & $\mathrm{X}$ & \\
\hline$\cdot \vec{\sigma}$ & Maintain sheet flow & $\mathrm{X}$ & $\mathrm{X}$ & & $\mathrm{X}$ & $\mathrm{X}$ \\
\hline $\begin{array}{l}\text { 仓̃ } \\
\stackrel{\Xi}{\Xi}\end{array}$ & $\begin{array}{l}\text { Clusters of trees and } \\
\text { shrubs in flow path }\end{array}$ & $\mathrm{X}$ & & & $\mathrm{X}$ & $\mathrm{X}$ \\
\hline$\frac{\mathscr{\Xi}}{\frac{0}{2}}$ & $\begin{array}{l}\text { Provide tree conservation/ } \\
\text { transition zones }\end{array}$ & $\mathrm{X}$ & & & & $\mathrm{X}$ \\
\hline $\overrightarrow{0}$ & Minimize storm drain pipes & $\mathrm{X}$ & $\mathrm{X}$ & $\mathrm{X}$ & $\mathrm{X}$ & $\mathrm{X}$ \\
\hline 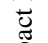 & Disconnect impervious areas & $X$ & & & $X$ & $\mathrm{X}$ \\
\hline 己̈ & Save trees & $\mathrm{X}$ & & & $\mathrm{X}$ & $\mathrm{X}$ \\
\hline 3 & Preserve existing topography & $\mathrm{X}$ & $\mathrm{X}$ & $\mathrm{X}$ & & \\
\hline 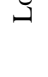 & $\begin{array}{l}\text { LID drainage and } \\
\text { infiltration zones }\end{array}$ & & $\mathrm{X}$ & $\mathrm{X}$ & & $\mathrm{X}$ \\
\hline
\end{tabular}

opment condition with no stormwater management BMPs. This hydrograph reflects a shorter time of concentration (Tc), and an increase in total site imperviousness than that of the predevelopment condition. The resulting hydrograph shows a decrease in the time to reach the peak runoff rate, a significant increase in the peak runoff and discharge rate and volume, and increased duration of the discharge volume.

- Hydrograph 3 represents the resulting post development hydrograph using the low-impact techniques to reduce impervious area and increase storage volume. There is a reduction in both post development peak rate and volume.

\section{Maintaining the predevelopment $T c$}

The LID hydrologic evaluation requires that the post development Tc be close to the predevelopment Tc. This is important because LID is based on a homogenous land cover and distributed retention and detention of on-site BMPs. The following site planning techniques can be used to maintain the existing Tc: 1) maintaining predevelopment flow path length by dispersing and redirecting flows using open swales and natural or vegetated drainage patterns, 2) increasing surface roughness (e.g., preserving woodlands, vegetated swales), 3) detaining flows (e.g., open swales, bioretention), 4) minimizing disturbances (minimizing compaction and changes to existing vegetation), 5) flattening grades in impacted areas, 6) disconnecting impervious areas (e.g., eliminating curb/gutter and redirecting down spouts), and 7) connecting pervious areas to vegetated areas.

Combined use of these techniques to reduce the

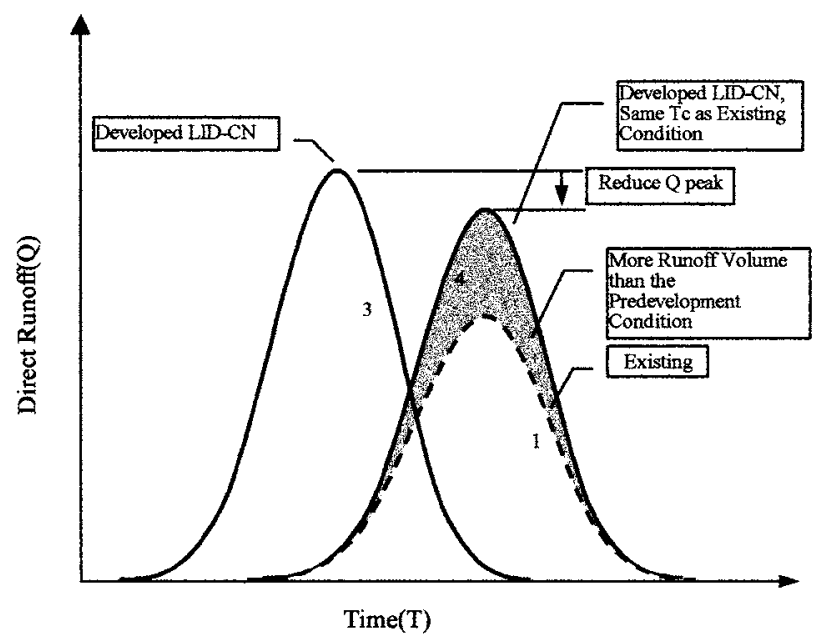

Fig. 2. Low-Impact Development hydrograph that has a reduced $\mathrm{CN}$ and maintains the Tc.

change in the $\mathrm{CN}$ can modify runoff characteristics to effectively shift the post development peak runoff time toward that of the predevelopment condition.

Fig. 2 illustrates the hydrologic response to maintain equal predevelopment and post development Tc.

- Hydrograph 3 refers to Fig. 1.

- Hydrograph 4 represents the effects of the Low-Impact Development techniques to maintain the Tc. This effectively shifts the post peak runoff time to that of the predevelopment condition and lowers the peak runoff rate.

Table 2 identifies Low-Impact Development techniques to maintain the predevelopment Tc. 


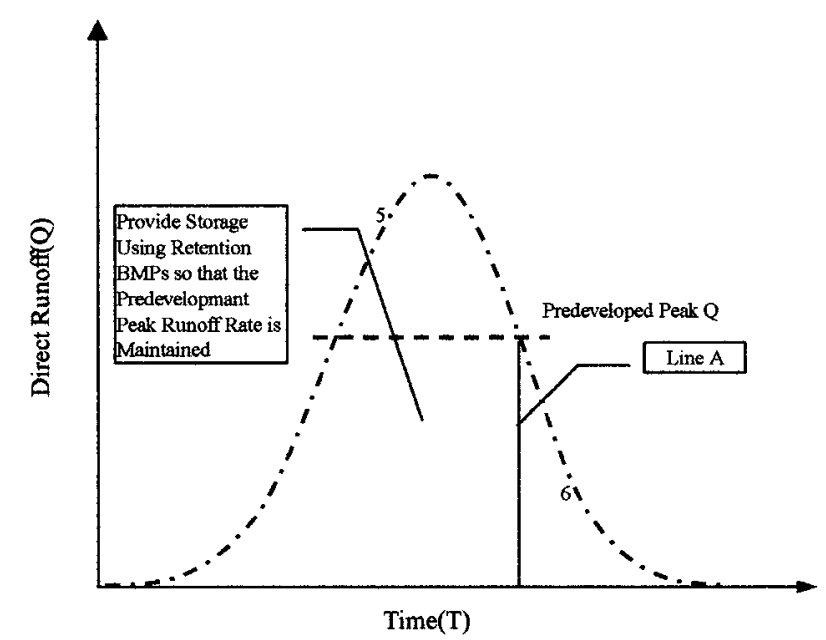

Fig. 3. Retention storage required to maintain peak development runoff rate.

\section{Maintaining the predevelopment $\mathrm{CN}$ and runoff volume}

Once the post development Tc is maintained at the predevelopment conditions and the change of predevelopment to post development $\mathrm{CN}$ is minimized, any additional reductions in runoff volume must be accomplished through distributed on-site stormwater management techniques. The goal is to select the appropriate combination of management techniques that simulate the hydrologic functions of the predevelopment condition to maintain existing $\mathrm{CN}$ and corresponding runoff volume. LID design strives to maximize the runoff use and retention practices distributed throughout the site to provide the required volume controls at the source.

Retention storage allows for a reduction in the post development volume and the peak runoff rate. The increased storage and infiltration capacity of retention BMPs allow the predevelopment volume to be maintained. The most appropriate on-lot retention BMPs include: 1) bioretention cells (rain gardens), 2) infiltration trenches, and 3) rain barrels. Other possible retention BMPs include: retention ponds, roof top storage, cisterns and irrigation ponds. It may be more difficult to distribute these types of controls throughout a development site, but often they are part of the site drainage patterns and have only to be left untouched.

As retention storage volume is increased there is a corresponding decrease in the peak runoff rate in addition to runoff volume reduction. If a sufficient amount of runoff is stored, the peak runoff rate may be reduced to a level at or below the predevelopment runoff rate. This storage may be all that is necessary to control the peak runoff rate when there is a small change in $\mathrm{CN}$.
However, when there is a large change in $\mathrm{CN}$, it may be less practical to achieve flow control using volume control only.

In Fig. 3, hydrograph 5 represents the retention BMP's inflow hydrograph for the post development condition for a site using Low-Impact Development retention BMPs. Because of the BMP's retention storage, runoff is not released until the maximum retention storage volume is exceeded. Line A represents the limit of retention storage. Hydrograph 6 is the outflow hydrograph from the Low-Impact Development retention BMPs. The release begins at the limit of retention storage, represented by line A. The storage maintains the predevelopment volume and controls the peak runoff rate. For this situation, the falling limb of the hydrograph represents a condition where the inflow (hydrograph 5) equals the outflow (hydrograph 6).

\section{Potential requirement for additional detention storage}

In cases where very large changes in $\mathrm{CN}$ can't be avoided, retention storage practices alone may be either insufficient to maintain the predevelopment runoff volume or peak discharge rates or require too much space to represent a viable solution. In these cases, additional detention storage will be needed to maintain the predevelopment peak runoff rates. A number of traditional detention storage techniques are available that can be integrated into the site planning and design process for a LID site. These techniques include: 1) swales with check dams, restricted drainage pipes, and inlet/entrance controls, 2) wider lower gradient swales, 3 ) rain barrels, 4) rooftop storage, 5) shallow parking lot storage, and 6) constructed wetlands and ponds. These detention practices can easily be integrated into the site design features.

The effect of this additional detention storage is illustrated in Fig. 4.

- Hydrograph 7 represents the response of a post development condition that incorporates Low-Impact Development retention practices. The amount of retention storage provided is not large enough to maintain the predevelopment peak runoff discharge rate. Additional detention storage is required.

- Hydrograph 8 illustrates the effect of providing additional detention storage to reduce the post development peak discharge rate to predevelopment conditions.

Where down stream flooding is a problem additional flow control may be necessary to protect property and ensure safe conveyance. Also, when there is a need to retrofit existing development additional detention may be needed to control off-site flows using regional ponds. 
Table 3. Examples of LID BMPs and primary functions

\begin{tabular}{|c|c|c|c|c|c|c|}
\hline BMP & Prevent runoff & Detention & Retention & Conveyance & Water quality & Stream channel protection \\
\hline Bioretention & & $\mathrm{X}$ & $\mathrm{X}$ & & $\mathrm{X}$ & $\mathrm{X}$ \\
\hline Infiltration trench & & $\mathrm{X}$ & $\mathrm{X}$ & & $\mathrm{X}$ & $\mathrm{X}$ \\
\hline Dry wells & & & $\mathrm{X}$ & & $\mathrm{X}$ & $\mathrm{X}$ \\
\hline Roof top storage & & $\mathrm{X}$ & $\mathrm{X}$ & & $\mathrm{X}$ & $\mathrm{X}$ \\
\hline Vegetative filter strips & & & & $\mathrm{X}$ & $\mathrm{X}$ & $\mathrm{X}$ \\
\hline Rain barrels & & $\mathrm{X}$ & $\mathrm{X}$ & & & $\mathrm{X}$ \\
\hline $\begin{array}{l}\text { Vegetated swales and } \\
\text { small culverts }\end{array}$ & & $\mathrm{X}$ & & $\mathrm{X}$ & $\mathrm{X}$ & $\mathrm{X}$ \\
\hline Swales & & $\mathrm{X}$ & & $\mathrm{X}$ & $\mathrm{X}$ & $\mathrm{X}$ \\
\hline Infiltration swale & & $\mathrm{X}$ & $\mathrm{X}$ & $\mathrm{X}$ & $\mathrm{X}$ & $\mathrm{X}$ \\
\hline Reduce imperviousness & $\mathrm{X}$ & & & & & $\mathrm{X}$ \\
\hline $\begin{array}{l}\text { Strategic clearing/ } \\
\text { grading }\end{array}$ & $\mathrm{X}$ & & & & $\mathrm{X}$ & $\mathrm{X}$ \\
\hline Engineered landscape & $\mathrm{X}$ & $\mathrm{X}$ & $\mathrm{X}$ & & $\mathrm{X}$ & $\mathrm{X}$ \\
\hline $\begin{array}{l}\text { Fliminate curb and } \\
\text { gutter }\end{array}$ & $\mathrm{X}$ & & & & $\mathrm{x}$ & $\mathrm{X}$ \\
\hline Vegetative buffers & $\mathrm{X}$ & & & & $\mathrm{X}$ & $\mathrm{X}$ \\
\hline
\end{tabular}

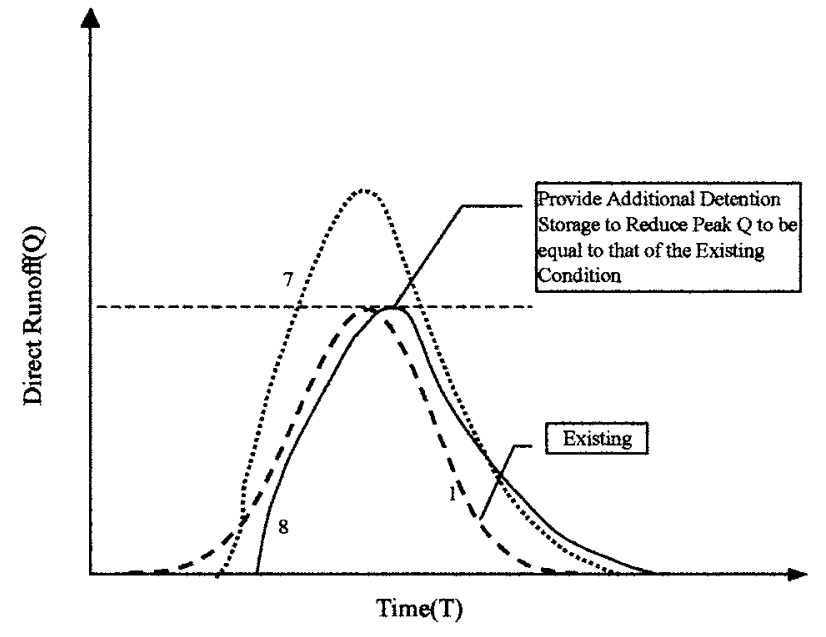

Fig. 4. Effect of additional detention storage on LID retention practices.

\section{DETERMINATION OF DESIGN STORM EVENT}

The hydrologic approach of LID is to retain the same amount of rainfall within the development site as that retained prior to any development (e.g., woods or meadow in good condition) and then release excess runoff as the woods or meadow would have. By doing so, it is possible to mimic, to the greatest extent practical, the predevelopment hydrologic regime to maximize protection to aquatic ecosystems and ground water recharge. This approach allows the determination of a design storm volume that is tailored to the unique soils, vegetation, and topographic characteristics of the watershed. This approach is particularly important in watersheds that are critical for ground water recharge to protect stream/wetland base flow and ground or surface water supplies. For each watershed there is a unique amount of runoff that must be retained to mimic the natural conditions. With LID the volume of runoff to be controlled changes with each site in order to replicate the natural watershed conditions.

\section{LID BEST MANAGEMENT PRACTICES}

Site design techniques and BMPs can be organized into three major categories as follows: 1) runoff prevention measures designed to minimize impacts and changes in predevelopment $\mathrm{CN}$ and $\mathrm{Tc}, 2$ ) retention facilities that store runoff for infiltration, exfiltration or evaporation, and 3) detention facilities that temporarily store runoff and release through a measured outlet. Table 3 lists only some of a wide array of LID's BMPs and their primary functions. Placing these BMPs in series (treatment train) and uniformly dispersing them throughout the site provides the maximum benefits for hydrologic controls.

A more completed list of LID practices (no limits) includes bioretention/rain gardens, strategic grading, site finger printing, resource conservation, flatter wider detention swales, flatter slopes, long flow paths, tree/ shrub depression, turf depression, landscape islands storage, rooftop detention/retention, roof leader disconnection, parking lot and street storage, small culverts/pipes/inlets, alternative surfaces, reduce impervious surface, surface roughness technology, rain 
barrels/cisterns/water use, catch basin/seepage pits, sidewalk storage, vegetative swales/buffers/strips, infiltration swales/trenches, eliminate curb and gutter, shoulder vegetation, maximize sheet flow, maintain flow path, reforestation, pollution prevention, etc. The list can go on and on.

\section{PUBLIC OUTREACH AND POLLUTION PREVENTION}

Pollution prevention and maintenance of on lot BMP's are two key elements in the overall LID comprehensive approach. Effective pollution prevention measures can reduce the introduction of pollutants to LID's BMPs thereby enhancing their ability to reduce pollutant levels and extend the life of the facilities. Public education is essential to successful pollution prevention and BMP maintenance. Not only will effect public education complement and enhance BMP effectiveness, it can also be used as a marketing tool to attract environmentally conscious buyers, promote citizen stewardship, awareness and participation in environmental protection programs and help to build a greater sense of community based on common environmental objectives and the unique environmental character of LID designs.

Education is the key to effective public participation. With LID techniques all stakeholders (public officials, engineers, builders, realtors, and buyers) must be educated about the positive environmental impacts of LID and its maintenance savings and burdens. With LID most controls are integrated into the lot landscape features therefore, property owners will need to know how to maintain these features. This can be achieved through easements, covenants, brochures, and environmental committees. Although additional landscape means more landscape maintenance, there is no major stormwater infrastructure (ponds, pipes or structures) to maintain and the scale of the maintenance is reduced to what an individual property owner can afford for routine landscape maintenance costs.

Property owners will respond to LID's landscape level of control in two very important ways. First, they feel good about their property helping to protect the environment. Second, they believe that the additional landscape material adds greater value to their property. Thus, LID's controls provide a strong economic incentive to maintain LID's practices because property values are also maintained.

\section{ROAD BLOCKS TO LID}

One of interesting results of LID's on lot microscale approach is that the stormwater management con- trols become a part of each property owner's landscape (natural areas, rain gardens, open space, open swales, etc). This reduces the public burden to maintain large centralized management facilities and reduces the cost and scale of maintenance to a level the homeowner can easily afford - the cost of routine landscape/yard care and pollution prevention. We believe the economic incentive of maintaining property values will ensure most property owners will adequate maintain their LID landscape.

There are a number of roadblocks that must be overcome for the successful implementation of LID. Regulatory agencies, the development community, and the public may all have concerns about the use of new technology. Some of the major concerns include: 1) development of a hydrologic analytical methodology to demonstrate the equivalence of LID to conventional approaches, 2) development of new road standards which allow for narrow roads, open drainage and use of bioretention, 3) streamlining the review process for innovative new LID designs which allow for easy modification of site, subdivision, road and stormwater requirements, 4) development of a public education process that informs property owners on how to prevent pollution and maintain on lot LID BMP's, 5) development of legal and educational mechanisms to ensure BMP maintenance, 6) demonstrating the marketability of green development, 7) demonstrating the cost benefits of the LID approach, 8) providing training for regulators, consultants, public and political leaders, 9) conducting research to demonstrate the effectiveness of BMP's, and 10) conducting field monitoring data to demonstrate the effectiveness of LID in controlling runoff quantity and quality.

\section{CONCLUSIONS AND SUMMARY}

LID is a viable cost effective alternative approach to stormwater management and the protection of natural resources. LID is designed to provide tangible economic incentives to a developer to save more natural areas and reduce stormwater and roadway infrastructure costs. LID can achieve greater natural conservation by using conservation as a stormwater BMP. As more natural areas are saved less runoff is generated and stormwater management costs are reduced. This allows multiple uses of landscape features to achieve environmental, economic, and aesthetic benefits.

Additionally, developers have economic incentives to provide better environmental protection by reducing short and long term infrastructure costs by reducing impervious areas, eliminate curbs/gutters and stormwater ponds to achieve LID stormwater controls. Reduction of the infrastructure also reduces infrastruc- 
ture maintenance burdens making LID development more economically sustainable. Since stormwater management is controlled on each lot using multifunctional landscapes, that portion of the building area that would have been used for stormwater ponds can, in some cases, be used for additional flood control and used for building, parking lots, open space or habitat enhancements.

LID promotes public awareness, education and participation in environmental protection. As every property owner's landscape functions as part of the watershed, they must be educated on the benefits and the need for maintenance of the landscape and pollution prevention measures. LID developments can be designed in a very environmentally sensitive manner to protect streams, wetlands, forests, and habitat and save energy. The unique environmental protection objectives of a LID development can create a greater sense of community pride based on environmental stewardship.

During the development of LID it was learned that current analytical models such as TR-55 or HEC-1 are not well suited for use with very small watersheds. There is a significant amount of work needed to upgrade current models to better quantify the affects of microscale site design control techniques.

\section{REFERENCES}

1. US Environmental Protection Agency (USEPA), Urbanization and Streams: Studies of Hydrologic Impacts, Office of Water, Washington, DC (1997).

2. Booth, D.B. and Reinelt, L.E., Consequences of Urbanization Aquatic Systems Measured Effects, Degradation Thresholds, and Corrective Strategies, Proceeding of Watershed'93 (1993).

3. Prince George's County, A Technical Manual for Woodland Conservation with Development, Maryland National Capital Planning Commission, MA (1990).

4. Horner, R.R., Skupien, J.J., Livingston, E.H. and Shaver, H.E., Fundamentals of Urban Runoff Management: Technical and Institutional Issues, Terrene Institute, Washington, DC (1994).

5. Takeuchi, K., "Japanese Flood Experiences in the $20^{\text {th }}$ Century and the Global Perspectives," $\mathrm{X}^{\text {th }}$ World Water Conference, Melbourne, Australia (2000).

6. Okamoto, M., "Comprehensive Sediment Control Measures," $\mathrm{X}^{\text {th }}$ World Water Conference, Melbourne, Australia (2000).

7. Seiji, M., "Flood Control Measures in Japan," $X^{\text {th }}$ World Water Conference, Melbourne, Australia (2000).

8. Prince George's County, Low-Impact Development Guidance Manual, Department of Environmental Resources, MA (1997).

9. Prince George's County, Design Manual for Use of
Bioretention in Stormwater Management, MA (1993).

10. Hall, M.J., Urban Hydrology, Elsevier Applied Science, London (1984).

11. Chow, V.T., Maidment, D., and Mays, L., Applied Hydrology, McGraw Hill, New York (1988).

12. Bedient, P.B., Huber, W.C., Hydrology and Floodplain Analysis, $2^{\text {nd }}$ Edition, Addision-Wesley, Reading, MA (1992).

13. McCuen, R.H., A Guide to Hydrologic Analysis Using SCS Methods, Prentice Hall Inc., Englewood Cliffs, NJ (1982).

14. McCuen, R.H., Hydrologic Analysis and Design, Prentice Hall Inc., Englewood Cliffs, NJ (1989).

15. US Department of Agriculture, National Engineering Handbook, Soil Conservation Service, Engineering Division, Washington, DC (1985).

16. US Department of Agriculture, Urban Hydrology for Small Watersheds-Technical Release 55, Soil Conservation Service, Engineering Division, Washington, DC (1986).

17. Mishra, S.K. and Singh, V.P., "Another Look at the SCS Method," J. of Hydrologic Engineering, Vol. 4, No. 3, pp. 257-264 (1999).

\section{低度影響遥流抑制技術一 暴雨遥流管理的新概念}

$$
\text { 廖朝軒蔡燿隆 }
$$

國立台灣海洋大學河海工程學系

$$
\text { 陳茂松 }
$$

\section{美國馬里蘭州喬治郡環境部技術處}

$$
\text { 摘 要 }
$$

爲了有效協助各級政府規劃更有效的暴雨遥流 管理措施, 一個嶄新的綜合暴雨遥流管理概念：低度 影響遥流抑制技術(Low-Impact Development, LID) 被提出並予探討, 低度影響遥流抑制技術應用了微尺 度及分散配置的管理技術; 本文簡要提出低度影響遥 流抑制技術的發展過程並探討其基本水文機制與控制 原則。同時, 低度影響遥流抑制技術所採用的中、上 游減洪方式, 在洪澇的發生地即削減洪水, 故其是一 種經濟且廣爲被接受的概念, 它可以更有效的管理新 開發地區或改進現存因開發所引起的水文平衡改變問 題。我們深信此新概念的提出將使暴雨管理技術朝向 更高層次的應用與發展領域上向前邁進一大步, 它將 提供一個具價值且有用的工具協助各級政府從事都市 暴雨遥流管理。 